(c) American Dairy Science Association, 2003.

\title{
Efficiency of Converting Nutrient Dry Matter to Milk in Holstein Herds ${ }^{1}$
}

\author{
J. S. Britt, ${ }^{\star}$ R. C. Thomas, $†$ N. C. Speer, ${ }^{\star}$ and M. B. Hall‡ \\ *Department of Agriculture, \\ Western Kentucky University, Bowling Green 42101-5376 \\ †College of Veterinary Medicine, \\ Auburn University, Auburn, AL 36849-5517 \\ $\ddagger$ Department of Animal Sciences, \\ University of Florida, Gainesville 32611
}

\begin{abstract}
Production of milk from feed dry matter intakes (DMI), called dairy or feed efficiency, is not commonly measured in dairy herds as is feed conversion to weight gain in swine, beef, and poultry; however, it has relevance to conversion of purchased input to salable product and proportion of dietary nutrients excreted. The purpose of this study was to identify some readily measured factors that affect dairy efficiency. Data were collected from 13 dairy herds visited 34 times over a 14mo period. Variables measured included cool or warm season (high ambient temperature $<21^{\circ} \mathrm{C}$ or $>21^{\circ} \mathrm{C}$, respectively), days in milk, DMI, milk yield, milk fat percent, herd size, dietary concentrations (DM basis) and kilograms of crude protein (CP), acid detergent fiber $(\mathrm{ADF})$, neutral detergent fiber (NDF), and forage. Season, days in milk, CP \% and forage \% of diet DM, and kilograms of dietary $\mathrm{CP}$ affected dairy efficiency. When evaluated using a model containing the significant variables, dairy efficiency was lower in the warm season (1.31) than in the cool season (1.40). In terms of simple correlations, dairy efficiency was negatively correlated with days in milk ( $\mathrm{r}=-0.529)$, DMI $(\mathrm{r}=-0.316)$, forage $\%(\mathrm{r}=-0.430), \mathrm{NDF} \%(\mathrm{r}=-0.308)$, and kilograms of forage $(\mathrm{r}=-0.516)$, NDF $(\mathrm{r}=-0.434)$, and $\mathrm{ADF}(\mathrm{r}=$ -0.313 ), in the diet, respectively. Dairy efficiency was positively correlated with milk yield $(r=0.707)$. The same relative patterns of significance and correlation were noted for dairy efficiency calculated with $3.5 \%$ fatcorrected milk yield. Diets fed by the herds fell within such a small range of variation (mean \pm standard deviation) for CP \% (16.3 \pm 0.696$), \mathrm{NDF} \%(33.2 \pm 2.68)$, and forage $\%(46.9 \pm 5.56)$ that these would not be expected
\end{abstract}

\footnotetext{
Received December 3, 2002.

Accepted June 2, 2003.

Corresponding author: J. S. Britt; e-mail: jenks.britt@wku.edu.

${ }^{1}$ This research was supported by the Florida Agricultural Experiment Station and approved for publication as Journal Series no. R-09508.
}

to be useful to evaluate the effect of excessive underfeeding or overfeeding of these dietary components. The negative relationships of dairy efficiency with increasing dietary fiber and forage may reflect the effect of decreased diet digestibility. The results of this study suggest that managing herd breeding programs to reduce average days in milk and providing a cooler environment for the cows may help to maximize dairy efficiency. The mechanisms for the effects of the dietary variables on dairy efficiency need to be understood and evaluated over a broader range of diets and conditions before more firm conclusions regarding their impact can be drawn.

(Key words: dairy efficiency, dairy cattle)

\section{INTRODUCTION}

Dairy efficiency defined as yield of milk per unit of dietary DM consumed provides a readily calculated measure of dairy herd productivity. With feed comprising the largest operating expense in the production of milk, efficiency of converting feed DM to milk may have use as a benchmark related to profitability for the efficacy of diet and herd management to convert purchased input to salable product. Additionally, if a consumed nutrient is not converted to a salable product (milk, meat, or calf), it will be excreted. It would seem that increased conversion of dietary DM to salable product at the same level of production has the potential to have a positive impact on farm profitability and nutrient management.

In a 24-h period, average lactating Holstein dairy cows typically consume feed DM equal to about $2 \%$ of their BW plus $1 \mathrm{~kg}$ of feed per each $3 \mathrm{~kg}$ of milk produced (McCullough, 1986). However, herds with nearly identical feedstuffs and nutrient intake often have different amounts of daily per cow milk production and dairy efficiency. It has been suggested that dairy efficiency should be in the range of 1.3 to $1.5 \mathrm{~kg}$ of solids-corrected milk per kilogram of DMI or greater in healthy and well-managed herds (Oetzel, 1998). Increased dairy ef- 
ficiency was reported to be related to greater daily milk yield, fewer DIM, body condition loss, high quality forages and improved feed digestibility, whereas low dairy efficiency was associated with greater DIM, proportion of the herd as first-lactation cows in the growth phase, gain of body condition, inclement environmental/ weather conditions, use of pasture, and ruminal acidosis (Hutjens, 2001; Hutjens, 2002). In one study, addition of buffers in the form of $\mathrm{NaHCO}_{3}$ and $\mathrm{MgO}$ to the diet decreased the gross efficiency of milk production (Arambel et al., 1988). As more grain was fed to cows on tropical pasture, efficiency of milk production decreased (Alhassan and Owusu, 1980). Dairy efficiency has not been evaluated in many studies; a broader array of research trials evaluating dairy efficiency would be useful to more accurately describe the factors that affect it.

Genetics may play a role in dairy efficiency, and milk yield corrected to a similar composition variable may be better to use to define dairy efficiency than using a ratio (Wang et al., 1991). Daughters from high genetic merit bulls produced more milk than did daughters of low genetic merit bulls even though feed intake was not different (Diab, 1992). The F1 Holstein-Jersey crosses demonstrated greater net energy efficiency than did purebred Holstein or Jersey cows (Schwager-Suter et al., 2001).

Veerkamp (1998) reported that it might be possible to improve economic efficiency for dairy cattle by selecting for feed intake, live animal weight, or other traits. Other factors that have been investigated for improving dairy efficiency include improving forage digestibility, which may influence the utilization of metabolizable energy for milk production (Gordon et al., 1995). In addition, improving NDF digestibility may increase milk yield (Oba and Allen, 1999).

The present study evaluated readily measurable factors obtained on a herd basis for their potential impact on dairy efficiency.

\section{MATERIALS AND METHODS}

All herds in this study were housed in free stalls, were composed of cows with Holstein genetics, were fed TMR, were milked in milking parlors, had computerized record-keeping systems, and used injectable bST.

Thirty-four data collection visits during a 14-mo period were made to 13 herds ranging from one to four visits per herd. With one exception, all dairies were visited at least once during the warm season (April 16 to October 15) and the cool season (October 16 to April 15). Owners or managers were present during all visits. The herds ranged in size from 47 to 634 lactating cows and were located in Kentucky ( $\mathrm{n}=9$ ), Tennessee ( $\mathrm{n}$ $=1)$, and Queretaro, Mexico $(\mathrm{n}=3)$. Information was collected using DHIA records (US herds = DRMS Raleigh, NC; Mexico herds = Holstein Mexico, Queretaro, QRO), ration formulation information, bulk tank milk weights, interviews, and other available farm records. Data collected included season of visit (cool or warm), milk fat \%, DIM, daily milk yield (kg/cow), percentages of ration $\mathrm{CP}, \mathrm{ADF}, \mathrm{NDF}$, and forage (DM basis), and group DMI. The "cool" season was defined as that time of year when the high 24-h ambient temperature did not exceed $21^{\circ} \mathrm{C}$, and the warm season as that portion of the year when the high ambient temperature exceeded $21^{\circ} \mathrm{C}$. Dairy efficiency and $3.5 \%$ FCM production were calculated from data collected on each herd. The 3.5\% FCM production was calculated on a per cow per day basis as $(16.23 \times$ milk fat kg $)+(0.432 \times$ milk kg $)($ derived from Tyrrell and Reid, 1965).

An average daily milk yield per lactating cow was calculated by dividing a 3 - to 6 -d bulk milk tank average by the number of lactating cows contributing milk to the tank. Milk processing plant records for each herd were the source for milk fat \% data. Ration data included mixer wagon scale amount of each ration offered in each 24-h period. The DM concentration of the ration was measured with a microwave oven and scales, and amount of DM consumed calculated as amount offered minus the weighed refusal. The concentrations of $\mathrm{CP}$, $\mathrm{ADF}$, and NDF (DM basis) of the diets were determined using analyses provided by the dairies. Analyses provided included wet chemistry analyses of the TMR, or wet chemistry analyses of the forages plus book or guaranteed values of commodity feeds. The average, standard deviation, minimum, and maximum values of the collected and calculated data are shown in Table 1.

\section{Statistical Analysis}

The data were evaluated using a combination of the regression and mixed model analysis procedures of SAS (2001). Dairy efficiency (milk yield $\mathrm{kg} \mathrm{cow}^{-1}$ per day divided by DMI kg cow ${ }^{-1}$ per day) or $3.5 \%$ fat-corrected dairy efficiency $\left(3.5 \% \mathrm{FCM} \mathrm{kg} \mathrm{cow}{ }^{-1}\right.$ per day divided by DMI kg cow ${ }^{-1}$ per day) were dependent variables. Independent variables excepting those used directly in the calculation of dairy efficiency were evaluated by regression analysis using a backwards elimination procedure (initial inclusion of all independent variables and sequential elimination of the variables with $P<$ 0.10) (SAS, 2001) to determine those with $P$-values < 0.10 . The independent variables evaluated included season (hot or cool season), DIM, dietary concentrations of $\mathrm{CP}$, forage, $\mathrm{ADF}$ and $\mathrm{NDF}$ as percentages of $\mathrm{DM}$, and dietary intake in kilogram weights of $\mathrm{CP}$, forage, $\mathrm{ADF}$, and NDF. The variables selected by the regression procedure then were incorporated into models that in- 
BRITT ET AL.

Table 1. Simple statistics of data for herds included in the study.

\begin{tabular}{|c|c|c|c|c|c|}
\hline Variable $^{1}$ & $\mathrm{~N}$ & Mean & SD & Minimum & Maximum \\
\hline Season & 34 & 1.47 & 0.51 & 1 & 2 \\
\hline Milk fat $\%$ & 34 & 3.71 & 0.19 & 3.4 & 4.3 \\
\hline DIM & 34 & 196 & 33 & 135 & 277 \\
\hline Number of cows in herd & 34 & 195 & 155 & 47 & 634 \\
\hline Milk yield, $\mathrm{kg} / \mathrm{d}$ & 34 & 29.5 & 2.89 & 22.1 & 37.9 \\
\hline $3.5 \%$ fat-corrected milk, $\mathrm{kg} / \mathrm{d}$ & 34 & 30.4 & 3.21 & 22.1 & 40.5 \\
\hline 150-d milk yield, kg/d & 34 & 32.5 & 2.85 & 24.4 & 37.9 \\
\hline $\mathrm{DMI}, \mathrm{kg} / \mathrm{d}$ & 34 & 21.8 & 1.61 & 16.8 & 24.5 \\
\hline \multicolumn{6}{|l|}{ Percentage of diet DM } \\
\hline $\mathrm{CP}$ & 34 & 17.6 & 0.69 & 16.3 & 19.0 \\
\hline $\mathrm{ADF}$ & 34 & 20.5 & 1.72 & 17.0 & 25.8 \\
\hline NDF & 34 & 33.2 & 2.68 & 24.0 & 39.0 \\
\hline Forage & 34 & 46.9 & 5.56 & 32.0 & 56.0 \\
\hline \multicolumn{6}{|l|}{ Content in diet, $\mathrm{kg} / \mathrm{d}$} \\
\hline $\mathrm{CP}$ & 34 & 3.84 & 0.39 & 2.77 & 4.55 \\
\hline $\mathrm{ADF}$ & 34 & 4.46 & 0.46 & 3.26 & 5.62 \\
\hline $\mathrm{NDF}$ & 34 & 7.22 & 0.81 & 5.20 & 8.62 \\
\hline Forage & 34 & 10.2 & 1.47 & 7.24 & 12.5 \\
\hline Dairy efficiency & 34 & 1.36 & 0.12 & 1.11 & 1.67 \\
\hline $3.5 \%$ FCM dairy efficiency & 34 & 1.40 & 0.13 & 1.12 & 1.79 \\
\hline
\end{tabular}

${ }^{1}$ Season: $1=\operatorname{cool}\left(<21^{\circ} \mathrm{C}\right), 2=$ warm $\left(>21^{\circ} \mathrm{C}\right)$; dairy efficiency = milk yield $\mathrm{kg} / \mathrm{DMI} \mathrm{kg} ; 3.5 \% \mathrm{FCM}$ dairy efficiency $=3.5 \% \mathrm{FCM} \mathrm{kg} / \mathrm{DMI} \mathrm{kg}$. Kilogram data are the average values per cow per day.

cluded "Farm" as a random classification variable. Although up to four visits were made to each farm, these were not treated as repeated measures because the lactating animals included in each herd would differ among visits. Although rates vary among herds, milking herd populations would expect to change yearly by $32 \%$ from culling and calving replacements, $5 \%$ from deaths and 15\% from animals drying off (DRMS, 1997). Animals in the herd on two consecutive visits would most likely be in different stages of lactation. The data were analyzed as a split plot design with "Herd" as the replication and "visit" as the main plot factor. In these models, the variable "season" was used as a classification variable. The effect of season on measures of production and dairy efficiency was evaluated in a model including all significant variables:

$$
\begin{gathered}
\mathrm{y}=\mu+\mathrm{H}_{\mathrm{i}}+\mathrm{V}_{\mathrm{j}}+\mathrm{HV}_{\mathrm{ij}}+\mathrm{S}_{\mathrm{k}}+\mathrm{D}_{\mathrm{l}}+\mathrm{C}_{\mathrm{m}}+\mathrm{F}_{\mathrm{n}}+\mathrm{P}_{\mathrm{o}} \\
+\varepsilon_{\mathrm{ijklmno}}
\end{gathered}
$$

where:

$$
\begin{aligned}
\mathrm{y}= & \text { dependent variable, } \\
\mu= & \text { true mean, } \\
\mathrm{H}_{\mathrm{i}}= & \text { herd }(\mathrm{i}=1,2, \ldots 13), \\
\mathrm{V}_{\mathrm{j}}= & \text { visit }(\mathrm{j}=1,2,3, \text { or } 4), \\
\mathrm{HV}_{\mathrm{ij}}= & \text { interaction term of herd and visit (error } \\
& \text { term for herd and visit), } \\
\mathrm{S}_{\mathrm{k}}= & \text { season }(\mathrm{k}=\text { cool or warm), } \\
\mathrm{D}_{\mathrm{l}}= & \text { days in milk, } \\
\mathrm{C}_{\mathrm{m}}= & \mathrm{CP} \% \text { of dietary } \mathrm{DM},
\end{aligned}
$$

$$
\begin{aligned}
\mathrm{F}_{\mathrm{n}} & =\text { forage } \% \text { of dietary } \mathrm{DM}, \\
\mathrm{P}_{\mathrm{o}} & =\text { kilograms of dietary CP intake, and } \\
\mathrm{e}_{\mathrm{ijklmn}} & =\text { residual error. }
\end{aligned}
$$

The difference in DIM by season were tested with the model:

$$
\mathrm{y}=\mu+\mathrm{H}_{\mathrm{i}}+\mathrm{S}_{\mathrm{j}}+\mathrm{HS}_{\mathrm{ij}}+\varepsilon_{\mathrm{ij}}
$$

where:

$$
\begin{aligned}
\mathrm{y} & =\text { dependent variable } \\
\mu & =\text { true mean } \\
\mathrm{H}_{\mathrm{i}} & =\text { herd }(\mathrm{i}=1,2, \ldots 13), \\
\mathrm{S}_{\mathrm{j}} & =\text { season }(\mathrm{j}=\text { cool or warm }), \\
\mathrm{HS}_{\mathrm{ij}} & =\text { interaction term for herd and season, and } \\
\varepsilon_{\mathrm{ij}} & =\text { residual error. }
\end{aligned}
$$

These models were statistically evaluated using the PROC MIXED procedure of SAS (2001). Additionally, simple correlations between continuous variables were evaluated using the PROC CORR procedure of SAS (2001).

\section{RESULTS AND DISCUSSION}

Season, DIM, CP \%, and forage \% of diet DM, and kilograms of dietary CP intake affected dairy efficiency and $3.5 \%$ FCM dairy efficiency $(P<0.05$; from regression and general linear model procedures). Dairy efficiency was highly and positively correlated to total milk 

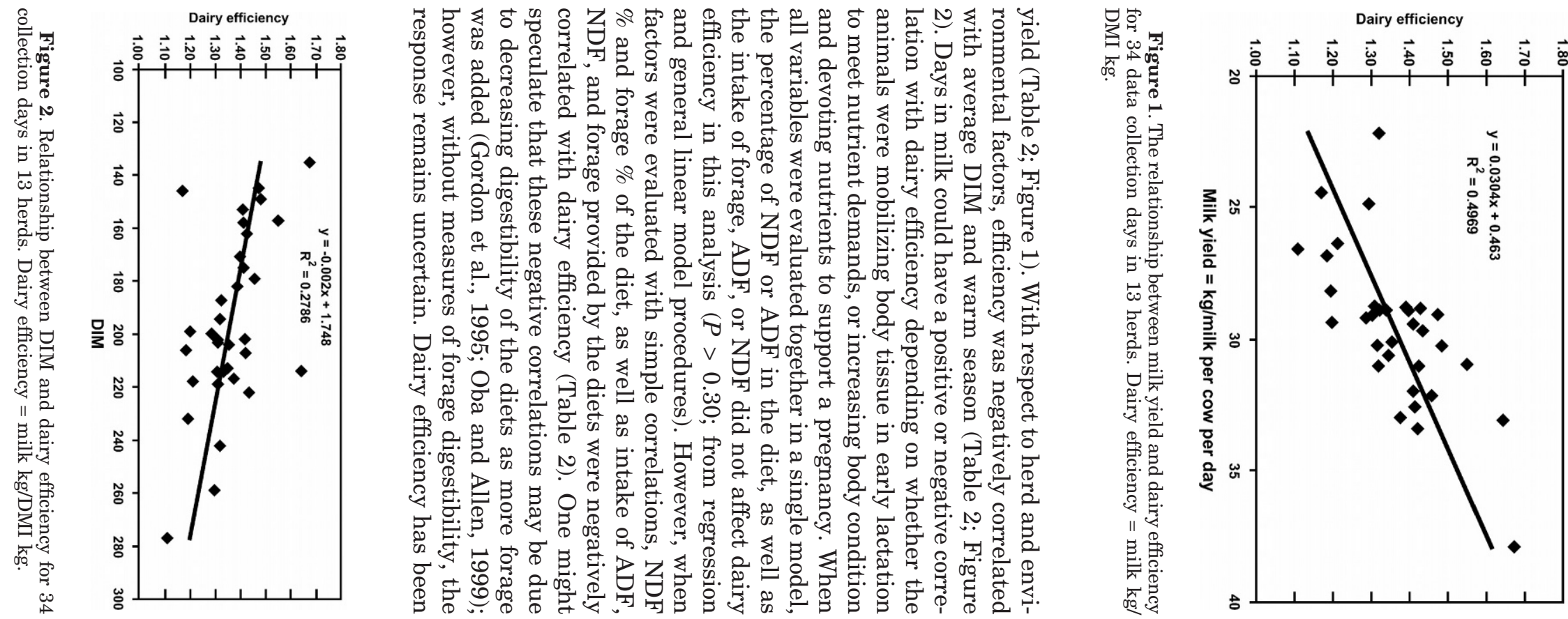

Table 2. Simple correlations among measures of production, intake and dairy efficiency and production performance, DIM, diet composition, and DMI. (Data for each item presented with the correlation on the first line and $P$-value on the second line and $P$-values $<0.05$ are bold).

\begin{tabular}{|c|c|c|c|c|c|c|c|c|c|c|c|c|c|c|}
\hline Item $^{1}$ & Season $^{2}$ & DIM & $\begin{array}{l}\text { Diet } \\
\text { CP\% }\end{array}$ & $\begin{array}{l}\text { Diet } \\
\text { ADF\% }\end{array}$ & $\begin{array}{l}\text { Diet } \\
\text { NDF\% }\end{array}$ & $\begin{array}{l}\text { Diet } \\
\text { forage } \\
\%\end{array}$ & $\begin{array}{l}\text { DMI, } \\
\mathrm{kg}\end{array}$ & $\begin{array}{l}\text { Diet } \\
\mathrm{CP}, \mathrm{kg}\end{array}$ & $\begin{array}{l}\text { Diet } \\
\mathrm{ADF}, \\
\mathrm{kg}\end{array}$ & $\begin{array}{l}\text { Diet } \\
\text { NDF, } \\
\mathrm{kg}\end{array}$ & $\begin{array}{l}\text { Diet } \\
\text { forage, } \\
\mathrm{kg}\end{array}$ & $\begin{array}{l}\text { Milk } \\
\text { fat } \\
\%\end{array}$ & $\begin{array}{l}\text { Milk } \\
\text { yield, } \\
\text { kg }\end{array}$ & $\begin{array}{l}3.5 \% \\
\text { FC } \\
\text { milk, kg }\end{array}$ \\
\hline Milk fat, $\%$ & $\begin{array}{r}-0.266 \\
0.128\end{array}$ & $\begin{array}{r}-0.363 \\
0.035\end{array}$ & $\begin{array}{r}-0.004 \\
0.983\end{array}$ & $\begin{array}{r}-0.029 \\
0.871\end{array}$ & $\begin{array}{l}0.093 \\
0.599\end{array}$ & $\begin{array}{l}0.048 \\
0.789\end{array}$ & $\begin{array}{l}0.178 \\
0.314\end{array}$ & $\begin{array}{l}0.122 \\
0.491\end{array}$ & $\begin{array}{l}0.106 \\
0.551\end{array}$ & $\begin{array}{l}0.185 \\
0.296\end{array}$ & $\begin{array}{l}0.139 \\
0.434\end{array}$ & 1.000 & $\begin{array}{l}0.175 \\
0.119\end{array}$ & $\begin{array}{l}0.410 \\
0.016\end{array}$ \\
\hline Milk, kg & $\begin{array}{r}-0.542 \\
0.001\end{array}$ & $\begin{array}{r}-0.420 \\
0.014\end{array}$ & $\begin{array}{l}0.473 \\
0.005\end{array}$ & $\begin{array}{r}-0.199 \\
0.259\end{array}$ & $\begin{array}{r}-0.259 \\
0.139\end{array}$ & $\begin{array}{l}0.384 \\
0.025\end{array}$ & $\begin{array}{l}0.445 \\
0.008\end{array}$ & $\begin{array}{l}0.504 \\
0.002\end{array}$ & $\begin{array}{l}0.143 \\
0.421\end{array}$ & $\begin{array}{l}0.090 \\
0.611\end{array}$ & $\begin{array}{r}-0.074 \\
0.678\end{array}$ & $\begin{array}{l}0.175 \\
0.322\end{array}$ & 1.000 & $\begin{array}{r}0.969 \\
<0.001\end{array}$ \\
\hline DMI, kg & $\begin{array}{r}-0.272 \\
0.120\end{array}$ & $\begin{array}{l}0.116 \\
0.515\end{array}$ & $\begin{array}{l}0.552 \\
0.001\end{array}$ & $\begin{array}{r}-0.128 \\
0.471\end{array}$ & $\begin{array}{l}0.055 \\
0.757\end{array}$ & $\begin{array}{l}0.031 \\
0.863\end{array}$ & 1.000 & $\begin{array}{r}0.940 \\
<0.001\end{array}$ & $\begin{array}{r}0.598 \\
<0.001\end{array}$ & $\begin{array}{r}0.684 \\
<0.001\end{array}$ & $\begin{array}{l}0.561 \\
0.001\end{array}$ & $\begin{array}{l}0.178 \\
0.314\end{array}$ & $\begin{array}{l}0.445 \\
0.008\end{array}$ & $\begin{array}{l}0.451 \\
0.007\end{array}$ \\
\hline $3.5 \% \mathrm{FCM}, \mathrm{kg}$ & $\begin{array}{r}-0.564 \\
0.001\end{array}$ & $\begin{array}{r}-0.476 \\
0.004\end{array}$ & $\begin{array}{l}0.437 \\
0.010\end{array}$ & $\begin{array}{r}-0.195 \\
0.268\end{array}$ & $\begin{array}{r}-0.219 \\
0.214\end{array}$ & $\begin{array}{r}-0.339 \\
0.050\end{array}$ & $\begin{array}{l}0.451 \\
0.007\end{array}$ & $\begin{array}{l}0.494 \\
0.003\end{array}$ & $\begin{array}{l}0.152 \\
0.390\end{array}$ & $\begin{array}{l}0.126 \\
0.479\end{array}$ & $\begin{array}{r}-0.033 \\
0.852\end{array}$ & $\begin{array}{l}0.410 \\
0.016\end{array}$ & $\begin{array}{r}0.969 \\
<0.001\end{array}$ & 1.000 \\
\hline Dairy efficiency & $\begin{array}{r}-0.364 \\
0.034\end{array}$ & $\begin{array}{r}-0.529 \\
0.001\end{array}$ & $\begin{array}{l}0.059 \\
0.739\end{array}$ & $\begin{array}{r}-0.102 \\
0.566\end{array}$ & $\begin{array}{r}-0.308 \\
0.076\end{array}$ & $\begin{array}{r}-0.430 \\
0.011\end{array}$ & $\begin{array}{r}-0.316 \\
0.069\end{array}$ & $\begin{array}{r}-0.209 \\
0.235\end{array}$ & $\begin{array}{r}-0.313 \\
0.071\end{array}$ & $\begin{array}{r}-0.434 \\
0.010\end{array}$ & $\begin{array}{r}-0.516 \\
0.002\end{array}$ & $\begin{array}{l}0.031 \\
0.863\end{array}$ & $\begin{array}{r}0.707 \\
<0.001\end{array}$ & $\begin{array}{r}\mathbf{0 . 6 6 4} \\
<0.001\end{array}$ \\
\hline $3.5 \%$ FCM DE & $\begin{array}{r}-0.414 \\
0.015\end{array}$ & $\begin{array}{l}-0.602 \\
<0.001\end{array}$ & $\begin{array}{l}0.060 \\
0.735\end{array}$ & $\begin{array}{r}-0.112 \\
0.528\end{array}$ & $\begin{array}{r}-0.274 \\
0.116\end{array}$ & $\begin{array}{r}-0.398 \\
0.020\end{array}$ & $\begin{array}{r}-0.252 \\
0.151\end{array}$ & $\begin{array}{r}-0.164 \\
0.355\end{array}$ & $\begin{array}{r}-0.274 \\
0.116\end{array}$ & $\begin{array}{r}-0.367 \\
0.033\end{array}$ & $\begin{array}{r}-0.456 \\
0.007\end{array}$ & $\begin{array}{l}0.304 \\
0.080\end{array}$ & $\begin{array}{r}0.723 \\
<0.001\end{array}$ & $\begin{array}{r}0.748 \\
<0.001\end{array}$ \\
\hline
\end{tabular}

${ }^{1} 3.5 \% \mathrm{FCM}=3.5 \%$ fat-corrected milk, dairy efficiency $=$ milk $\mathrm{kg} / \mathrm{DMI} \mathrm{kg}, 3.5 \% \mathrm{FCM} \mathrm{DE}=3.5 \%$ fat-corrected milk $\mathrm{kg} / \mathrm{DMI} \mathrm{kg}$. All values are on a per cow per day basis.

${ }^{2}$ Season: $1=$ cool, 2 = warm. 
Table 3. Effect of season on milk yield, dairy efficiency, DMI, and milk fat percentage (values presented as least squares means).

\begin{tabular}{lccc}
\hline & Warm $^{1}$ & Cool $^{1}$ & $P$-value \\
\hline Milk yield, kg cow $^{-1}$ day $^{-1}$ & 28.5 & 30.5 & 0.029 \\
3.5\% FCM yield, kg cow & \\
Milk fat, $\%$ & 29.2 & 31.5 & 0.025 \\
DMI, kg cow $^{-1}$ day $^{-1}$ & 3.68 & 3.75 & 0.279 \\
Dairy efficiency & 21.7 & 21.8 & 0.301 \\
3.5\% FCM dairy efficiency & & 1.40 & 0.026 \\
Average DIM & 1.31 & 1.45 & 0.023 \\
\hline
\end{tabular}

${ }^{1}$ Season: High 24 -h ambient temperature did not exceed $21^{\circ} \mathrm{C}=$ cool, or exceeded $21^{\circ} \mathrm{C}=$ warm.

${ }^{2}$ Dairy efficiency $=$ milk yield $\mathrm{kg} / \mathrm{DMI} \mathrm{kg}$.

${ }^{3} 3.5 \%$ FCM dairy efficiency $=3.5 \%$ FCM kg/DMI kg.

reported to decline with ruminal acidosis (Hutjens, 2001, 2002), in which case dairy efficiency might be expected to increase with increased inclusion of forage or fiber in the diet. However, the range of dietary concentrations of $\mathrm{ADF}, \mathrm{NDF}$, and forage in this study were relatively narrow (Table 1) and so do not allow exploration of the effects of excessive underfeeding or overfeeding of these dietary components.

Season affected actual and 3.5\% FCM yield (Table 3) with production lower in the warm season. Herd DIM was greater in the warm season. A greater proportion of herds had dairy efficiency scores below 1.4 during the warm season (69\%) than during the cool season (39\%). A decrease in milk production rather than a change in DMI appears to explain the change in efficiency (Table 3). The increase in maintenance associated with heat stress would divert nutrients from productive purposes and thus result in decreased dairy efficiency (NRC, 1981). Additionally, the increased DIM in the warm season also offers the possibility that the later-lactation animals could have been devoting a greater proportion of dietary nutrients to pregnancy and increase in body condition, thus decreasing dairy efficiency. To properly evaluate the effect of season, the pattern of ambient temperatures above, below, and at thermoneutrality would have to be measured to esti-

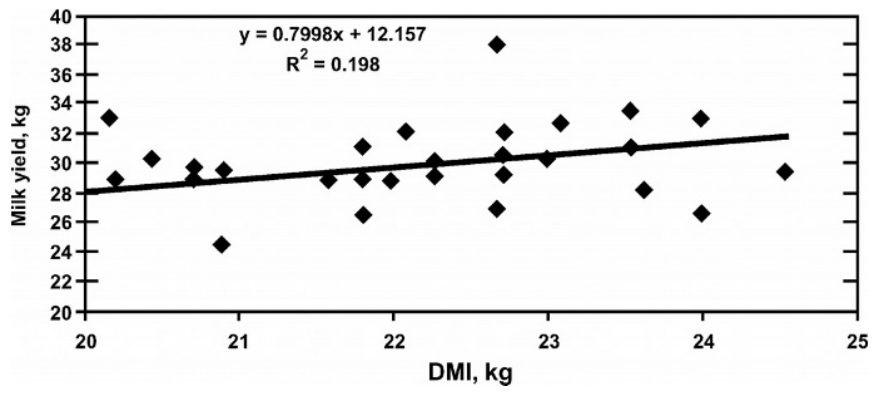

Figure 3. The relationship of milk yield and DMI for 34 data collection dates in 13 herds. Milk yield = kg/milk per cow per day. mate changes in maintenance requirements relative to temperature because maintenance requirements increase under both heat and cold stress (NRC, 1981). Information associated with ambient temperature could be more broadly applicable than season alone.

Among the herds studied, DMI was positively related to milk yield (Table 2; Figure 3) but was negatively correlated with dairy efficiency (Table 2; Figure 4). The relationship between intake and milk yield must be evaluated with consideration of other factors altering use of ingested nutrients including diet digestibility, changes in requirements for uses other than lactation (pregnancy, growth, heat or cold stress, exercise), and changes in BCS. Individual animal factors that are more difficult to measure such as disease and chronic discomfort may also affect dairy efficiency as they affect animal maintenance requirements.

\section{IMPLICATIONS}

Dairy efficiency is a measure of the ability of the cow to convert feed to milk. The results of this study suggest that managing herd breeding programs to reduce average DIM and perhaps providing a cooler environment for the cows during the warm season may help to in-

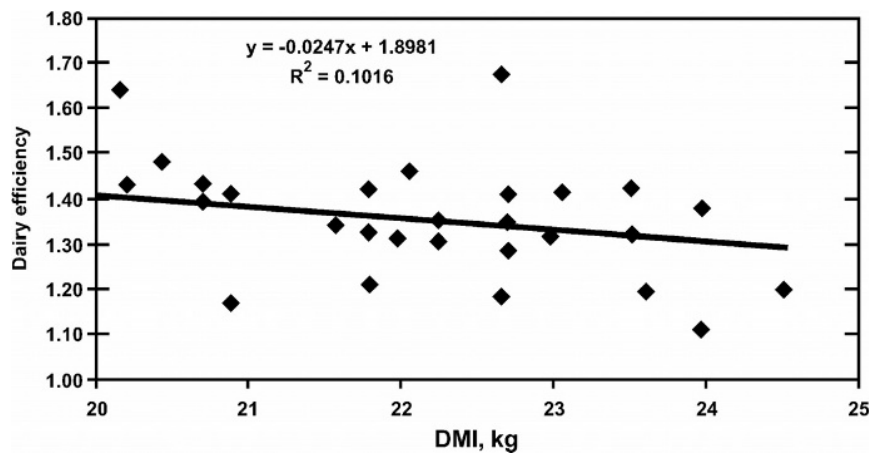

Figure 4. The relationship of DMI to dairy efficiency for 34 data collection days in 13 herds. Dairy efficiency $=$ milk kg/DMI kg. 
crease dairy efficiency. The basic concepts of decreasing maintenance requirements or dilution of maintenance with cows capable of producing greater amounts of milk can be applied to a variety of situations (e.g., disease, increased activity, cold or heat stress). If the relative proportion of nonlactation nutrient demands can be reduced, there is the potential for more dietary nutrients to be used for milk production, and for dairy efficiency to be increased.

\section{REFERENCES}

Alhassan, W. S., and D. Y. Owusu 1980. Lactation responses of dairy cattle to concentrate feeding in the humid tropics. Trop. Anim. Health Prod. 12.3:171-176.

Arambel, M. J., R. D. Weidmeier, D. H. Clark, R. C. Lamb, R. L. Bowman, and J. L. Walters. 1988. Effect of sodium bicarbonate and magnesium oxide in an alfalfa-based total mixed ration fed to early lactating dairy cattle. J. Dairy Sci. 71:159-163.

DRMS, Dairy Management Record Systems, Raleigh, NC. 1997. Yearly summary.

Diab, I. A. K. 1992. Effect of genetic merit on production and physiology measurements in dairy cattle. Ph.D. dissertation, Washington State University, Pullman.

Gordon, F. J., M. G. Porter, C. S. Mayne, E. F. Unsworth, and D. J. Kilpatrick. 1995. Effect of forage digestibility and type of concen- trate on nutrient utilization by lactating dairy cattle. J. Dairy Res. 62:15-27.

Hutjens, M. 2001. Where are you on feed cost? Hoard's Dairyman, Jan 20.

Hutjens, M. 2002. Using dairy efficiency. Online. Available: http:// dairynet.outreach.uiuc.edu/fulltext.cfm?section=2\&document $\mathrm{ID}=463$.

McCullough, M. E. 1986. Page 35 in Feeding Dairy Cattle. W. D. Hoard \& Sons, Ft. Atkinson, WI.

National Research Council. 1981. Effect of Environment on Nutrient Requirements of Domestic Animals. National Academy Press, Washington, DC.

Nordlund, K. 1995. Page 9 in Goal Form Production Medicine I. School of Veterinary Medicine, University of Wisconsin-Madison.

Oba, M., and M. Allen. 1999. Evaluation of the importance of the digestibility of neutral detergent fiber from forages: Effects on dry matter intake and milk yield of dairy cows. J. Dairy Sci. 82:589-596.

Oetzel, G. 1998. Troubleshooting the High Intake Herd. DHMCP School of Veterinary Medicine, University of Wisconsin-Madison.

Schwager-Suter, R., C. Stricker, D. Erdin, and N. Kunzi. 2001. Net efficiencies of Holstein, Jersey and Holstein-Jersey F1-crosses. 2001. Br. Soc. Anim. Sci. 72-2:335-342.

Tyrrell, H. F., and J. T. Reid. 1965. Prediction of the energy value of cow's milk. J. Dairy Sci. 48:1215-1223.

Veerkamp, R. F. 1998. Selection for economic efficiency of dairy cattle using information on live weight and feed intake: A review. J. Dairy Sci. 81:1109-1119.

Wang, S., G. L. Roy, A. J. Lee, A. J. McAllister, T. R. Batra, and C. Y. Lin. 1992. Evaluation of various measures of and factors influencing feed efficiency of dairy cattle. J. Dairy Sci. 75:1273-1280. 